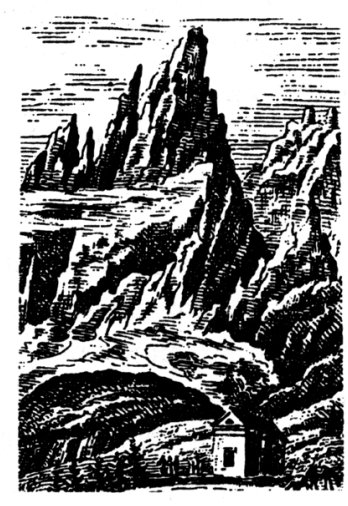

Szymon Makuch

Honorowy Konsulat Łotwy we Wrocławiu

szymonmakuch@wp.pl

DOI: $10.19195 / 2084-4107.11 .29$

\title{
Górski wehikuł czasu. Legenda Rogera Dodswortha w literaturze i kulturze
}

Słowa-klucze: Góry, literatura, historia, fantastyka

Keywords: mountains, literature, history, fantasy

\section{A mountain time machine. The legend of Roger Dodsworth in literature and culture}

\section{Summary}

In various legends and literary works the mountains often served as a place where time travel was possible, as they provided security for protagonists falling into deep sleep for years. It is no coincidence that legends of sleeping knights often place them in the mountains. In 1826 a rumour spread that Roger Dodsworth, who had been buried in an avalanche over 100 years earlier, came to life. The news was circulated by the press across Europe and attracted the interest of Mary Shelley, who devoted a short story to it. The present article is an analysis of press stories concerning the famous hibernatus and the story by the English writer, who saw the popular rumours as a background for reflections on a man from a different period transferred into the future, as well as an attempt to define the role of the mountains in the writings on Dodsworth. 


\section{Wprowadzenie}

Górskie przestrzenie zyskały w różnych tekstach literackich wiele funkcji. Ciekawym polem badawczym wydaje się ich rola jako miejsc umożliwiających swoiste podróże w czasie. Przed wiekami nie brakowało legend o bohaterach śpiących w jaskiniach u podnóża świętych gór (Karol Wielki, Fryderyk Barbarossa, Bolesław Chrobry) ${ }^{1}$. Wierzono również, że górskie tereny były bramami do tzw. zaginionych światów, a więc miejsc, gdzie rozwój cywilizacyjny został opóźniony (albo przebiegł zdecydowanie inaczej), przetrwały prehistoryczne stworzenia lub ludzie żyli w arkadyjskich warunkach. W beletrystyce realizacjami podobnych koncepcji są Zaginiony świat (1912, pol. 1913) Arthura Conan Doyle'a czy Zaginiony horyzont (1933, pol. 1939) Jamesa Hiltona.

Kolejnym źródłem przypisywania górom roli swoistego wehikułu czasu jest wiara w możliwość konserwowania żywych organizmów przez ich zamrożenie. Znalazła ona swój początek w odkryciach świetnie zachowanych zamrożonych mamutów na Syberii lub innych zwierząt w górskich lodowcach. Widok ciał niewiele różniących się, na pierwszy rzut oka, od żywych rodził pytania o możliwość „obudzenia” ich. Z czasem doprowadziło to do powstania teorii dotyczących krioniki i ich praktycznych realizacji w postaci zamrażania ludzkich ciał².

Interesującym przykładem dziewiętnastowiecznej plotki dotyczącej wybudzenia z hibernacji są doniesienia prasowe na temat Rogera Dodswortha, którego w 1826 r. rzekomo odkryto w alpejskiej jaskini i rozmrożono po ponad 160 latach. Temat odbił się szerokim echem w całej Europie i choć zainteresowanie nim było dość krótkie, to zdążyło zainspirować Mary Shelley do poświęcenia mu krótkiego utworu. Przedmiotem niniejszych rozważań jest omówienie prasowych doniesień na temat Dodswortha, a także przyjrzenie się jego wpływowi na późniejsze teksty kultury.

\section{Motywy snu/letargu w literaturze}

Motywy długoletniego lub wielowiekowego snu są w tekstach kultury obecne od bardzo dawna. Wspomniane już legendy o śpiących bohaterach, na których powrót czekają różne plemiona i narody, obecne są $\mathrm{w}$ dziesiątkach podań z różnych

1 Przykładowy wykaz takich narracji zob. http://www.pitt.edu/ dash/sleep.html (dostęp: 29.11.2013). Zawiera on podania z Niemiec, Szwajcarii, Szkocji czy Anglii. Zob. także F. Ziejka, Z dziejów literackiej sławy śpiących rycerzy, „Pamiętnik Literacki” 1983, z. 2; B. Grabowski, Podania o śpiacych rycerzach, „Bluszcz” 1881, nr 40, s. 314-315; nr 41, s. 323-324; nr 42, s. 331-332; W. Weryho, Śpiacy rycerze, „Wisła” 3, 1889, z. 2, s. 845-859; J. Hajduk-Nijakowska, Temat śpiacego wojska w folklorze polskim. Próba typologii, Opole 1980.

2 Ideą krioniki jest konserwacja ciał ludzi nieuleczalnie chorych, zwykle tuż po śmierci. Wiąże się z nadzieją, że w przyszłości medycyna może się na tyle rozwinąć, by przywrócić chorego do zdrowia. Pierwsi „krionauci” zostali umieszczeni w specjalnych zbiornikach w drugiej połowie lat sześćdziesiątych XX w. w Stanach Zjednoczonych.

Góry, Literatura, Kultura 11, 2018

(C) for this edition by CNS 
stron świata. Do najbardziej popularnych baśni należą historie o śpiącej królewnie czy królewnie Śnieżce, zawierające motyw letargu. W niektórych chrześcijańskich legendach wieloletni sen bohatera wprowadzano jako egzemplum ilustrujące nieskończoną boską moc. Przykładem jest opowieść Mnich i wieczność, w której Bóg kilkusetletnim snem poucza duchownego, niemogącego zrozumieć idei wieczności ${ }^{3}$.

W narracjach fantastycznych z XVIII i XIX w. motyw snu pełnił zwykle rolę wehikułu czasu. Celem było umieszczenie bohatera w późniejszej epoce, by tam ukazać wizję nowego społeczeństwa (np. w powieści $W$ roku 2000 Edwarda Bellamy'ego, 1887, pol. 1890; opowiadaniu Washingtona Irvinga Rip Van Winkle, 1819, pol. 1966), pouczyć go, zmienić jego charakter (Frances Sheridan, Nurzahad, człowiek nieśmiertelny, 1765, pol. 1784 oraz jego adaptacja sceniczna autorstwa Louis-Charles'a Caigniez Nurzahad i Szeredin, 1805, pol. 1815).

Po 1895 r., kiedy Herbert George Wells wydał swój Wehikuł czasu (pol. 1925), fabularne podróże w przyszłość częściej odbywały się z wykorzystaniem maszyn zaprojektowanych przez genialnych naukowców, magiczny sen zaś zastąpiony został hibernacją lub inną formą letargu (The Jameson Satellite Neila R. Jonesa, 1931; Synteza Macieja Wojtyszki, 1978; Homo Divisus Konrada Fiałkowskiego, 1979). W większości wypadków fabuły zawierały próby racjonalnego wyjaśnienia owego zjawiska. Nie brak jednak kilku dwudziestowiecznych przykładów klasycznych wątków magicznego lub niewyjaśnionego snu, jak w Pluskwie Włodzimierza Majakowskiego (1929, pol. 1956) czy w literaturze dziecięcej. Wciąż jednak zasadniczą funkcją takich motywów było nie tyle przedłużenie ludzkiego życia, ile po prostu wysłanie bohaterów w mniej lub bardziej odległą przyszłość.

\section{Tło naukowe i kulturowe}

Przełom XVIII i XIX w. miał zasadnicze znaczenie dla przemian w myśleniu o możliwościach walki ze śmiercią na wielu płaszczyznach. Słabła wiara w magię, istnienie kamienia filozoficznego i rozmaitych eliksirów życia, coraz popularniejsze zaś stawało się przekonanie o możliwości odkrycia naukowych metod przedłużania ludzkiego życia. Rozwinęły się techniki reanimacyjne, między innymi sztuczne oddychanie, oraz inne działania, pozwalające na zwiększenie szans przeżycia wypadków ${ }^{4}$. Eksperymenty z magnetyzmem i elektrycznością, działalność Franza Antona Mesmera (teorie magnetyzmu) czy Luigiego Galvaniego (elektryczność w tkankach zwierzęcych) spotkały się z entuzjazmem niektórych środowisk. Giovanni Aldini w latach 1802-1803 prowadził badania mające na celu ożywienie ciał kryminalistów. Wpłynęło to na rozwój motywów wskrzeszania umarłych, które w literaturze funkcjonowały od czasów antycz-

${ }^{3}$ Mnich i wieczność, [w:] Legendy chrześcijańskie. Antologia, t. 1, wyb. S. Klimaszewski, L. Santucci, wprow. S. Klimaszewski, Warszawa 2006, s. 286-287 .

${ }^{4}$ Zob. np. Ch. Kite, An Essay on the Recovery of the Apparently Dead, London 1788. 
nych, jednak do początków XIX w. traktowane były wyłącznie jako sfera związana z magią i siłami boskimi (lub piekielnymi) ${ }^{5}$.

W XIX w. od czasu do czasu w jarmarcznych broszurach ukazywały się doniesienia o cudownych zdarzeniach. I tak jak w XVII w. regularnie pojawiali się ludzie, którzy spotkać się mieli z Żydem Wiecznym Tułaczem lub nieśmiertelnym alchemikiem, tak w XVIII i XIX w. popularność zdobywały sensacje na temat osób przeżywających długotrwały sen. W krążących drukach regularnie pojawiał się wątek ludności nazywanej „Leukomori”. Według relacji barona Herbersteina miała to być ludność z terenów Wielkiego Księstwa Moskiewskiego, zamieszkująca okolice rzeki Ob. Pisano, że 27 listopada każdego roku zapadali oni w rodzaj zimowego snu, z którego budzili się 23 lipca ${ }^{6}$.

Badania naukowe nad procesami zamarzania i rozmrażania tkanek żywych organizmów były na przełomie XVIII i XIX w. na porządku dziennym. Rozważania na ten temat prowadził już zresztą w XVII w. Robert Boyle, głęboko zainteresowany konsekwencjami poddawania różnych substancji, a także ciał żywych chłodzeniu i ogrzewaniu? ${ }^{7}$. Chirurg John Hunter w 1766 r. przeprowadził eksperymenty, zamrażając żywe karpie. Efektem była śmierć zwierząt. Co ważne, w swoich notatkach zwracał uwagę, że wcześniej wierzył, iż mógł dowolnie hibernować i ożywiać ludzi. Wspomina, że widział dla siebie szansę na zdobycie fortuny dzięki zapewnianiu innym opcji na zamrażanie się i budzenie co 100 lat, by obserwować zmiany na świecie ${ }^{8}$. Podobne badania prowadził sir Everard Home, dochodząc do wniosku, dzięki obserwacji żabich mózgów, że w wypadku zamrożenia tego organu zmiany będą nieodwracalne i nie będzie możliwości przywrócenia organizmu do życia9

\section{Legenda Rogera Dodswortha}

Historia Rogera Dodswortha nie była zapewne pierwsza wśród doniesień o możliwości obudzenia człowieka ze stanu hibernacji, ale z pewnością najgłośniejsza. Zaczęła się od tekstu o hibernatusie ze szwajcarskiej jaskini w „Journal du Commerce de Lyon" z 28 czerwca 1826 r. Angielskie tłumaczenie notki ukazało się 4 lipca 1826 r. w londyńskim „New Times”. Krótki artykuł wskazywał,

5 E. Anastasaki, The trials and tribulations of the "revenants": Narrative techniques and the fragmented hero in Mary Shelley and Théophile Gautier, „Connotations” 2006/2007, nr 16, s. 26.

${ }^{6}$ A relation of an Extraordinary Sleepy Person At Tinsbury, near Bath, [w:] W. Oliver, A Practical Dissertation on Bath Waters, London 1707, s. 130-131.

7 Zob. History of Artificial Cold, Scientific, Technological and Cultural Issuess, red. K. Gavroglu, Dordrecht 2014, s. 25 n.

8 J. Hunter, The Works of John Hunter, F.R.S. with notes, red. J.F. Palmer, t. 1, London 1835, s. 284.

${ }^{9}$ Microscopical observations on the materials of the brain, and the ova of animals, to show the analogy that exist between them, by sir Everard Home, „The Edinburgh Medical and Surgical Journal" 26, 1826, s. 131. 
że dr James Hotham z Morpeth w hrabstwie Northumberland w trakcie podróży przez Szwajcarię, u podnóży góry św. Gotharda, miał znaleźć w jaskini mężczyznę wyglądającego na 30 lat, zamrożonego w bryle lodu. Nakazał jego wyniesienie, a następnie przez stopniowe podnoszenie temperatury ciała pacjenta doprowadził do jego przebudzenia. Dodsworth powiedział, że urodził się w 1629 r., a w 1660 r. przysypała go lawina. Bohater sensacyjnego doniesienia przedstawić się miał jako syn historyka Rogera Dodswortha, zmarłego w 1659 r. Jak zwraca jednak uwagę Charles E. Robinson, Dodsworth senior naprawdę zmarł w $1654 \mathrm{r}$. Źródła milczą też o jego potomstwie. We wspomnianym francuskim czasopiśmie wątku angielskiego hibernatusa nie kontynuowano. Żaden $\mathrm{z}$ angielskich dziennikarzy nie zebrał również później informacji o Jamesie Hothamie. Cytowany badacz dodaje, że historie familii Hothamów nie zawierają wzmianek na temat takiej osoby ${ }^{10}$.

Krótką historię publikowały potem między innymi „Belfast Commercial Chronicle”, „Berkshire Chronicle”, „Birmingham Journal”, „Morning Chronicle”, „Sun”, „Public Ledger, and Daily Adertiser”, „Durham Chronicle”, „Hereford Journal”, „Sussex Advertiser”, ,Southern Reporter and Cork Commercial Courier”, „Lancaster Gazette”, „Northampton Mercury”, „Manchester Guardian” czy „Scotsman”. W gazecie „John Bull” natomiast redaktor Theodore Hook pisal o przyjeździe Dodswortha do Londynu i zamieszkaniu przezeń w St. James's Palace. Dodawał, że długowieczny mężczyzna miał początkowo wyglądać słabo, prawie jak martwy ${ }^{11}$.

Wkrótce poetycki komentarz do utworu opublikował Thomas Moore ${ }^{12}$ najpierw w „Timesie”, a potem także w „Pertshire Courier”. Większość tekstów prasowych była przedrukiem pierwotnej notatki, pozbawionym jakiegokolwiek komentarza lub polemiki. Dopiero 15 lipca 1826 r. w piśmie „Manchester Courier and Lancashire General Advertiser" obok przepisania głównego doniesienia dziennikarze poprowadzili szersze refleksje o cudownym odkryciu Hothama. Co ważne, rozważając problem od strony naukowej, stwierdzono, że skoro możliwe jest ożywienie osoby niemalże utopionej, to może i reanimacja zamrożonego ciała jest możliwa. Przywołano też przykłady zwierząt zapadających w zimowe odrętwienie.

We wrześniu 1826 r. Dodsworth postanowił wykorzystać sławę i wysyłał listy do redakcji, które publikowano w piśmie „John Bull” (pierwsze dwa), a potem w konkurencyjnym „New Monthly Magazine”13. Pierwszy, sygnowany datą 29 sierpnia 1826 r., zawiera między innymi refleksje o ,przespaniu” przez bohatera wielkiego pożaru Londynu z 1666 r., który sprawił, że znikło wiele miejsc,

10 Ch.E. Robinson, Mary Shelley and the Roger Dodsworth Hoax, „Keats-Shelley Journal” 24, 1975, s. 21.

11 Za: ibidem, s. 22.

12 T. Moore, The Poetical Works in Five Volumes, t. 4, Leipzig 1842, s. 321.

13 Jak pisze Robinson, miało to mocno zdziwić redaktora „Johna Bulla” Theodore'a Hooka — Ch.E. Robinson, op. cit., s. 24. 
które mężczyzna pamiętał. Drugi list, z datą 12 września, przedstawia podróże Dodswortha po Londynie i refleksje na temat zapamiętanych miejsc. Nieregularne publikacje korespondencji Anglika pojawiały się do $1829 \mathrm{r}$.

Uwagę zwracać mógł list z 21 lipca 1827 r. w „Berkshire Chronicle”, w którym Dodsworth pisał o swoich przeżyciach w nowym świecie. 11 sierpnia 1827 r. w tym samym czasopiśmie twierdził natomiast, że wcześniejsze publikacje w „Johnie Bullu” nie były jego autorstwa. W liście opublikowanym 13 października 1827 r. w „Berkshire Chronicle” Dodsworth skarżył się, że wielu niedowiarków chciałoby go spotkać i zbadać. Deklarował też przybycie do redakcji gazety. 11 kwietnia 1829 r. opublikowano zaś jego list do króla Jerzego IV. 5 września 1829 r. na łamach „Berkshire Chronicle” ukazał się list Dodswortha, w którym przeprasza on za długie milczenie, wskazując wśród jego przyczyn miłość i planowany ślub. W późniejszych latach zainteresowanie tematem zanikło.

Sława Anglika dotarła również do Polski. W „Gazecie Korrespondenta Warszawskiego i Zagranicznego" już 15 lipca 1826 r. zamieszczono następującą notatkę:

Doktor Jakob Hotham de Morpet z Northumberland, powracając ze Szwajcarii, opowiadał nadzwyczajne zdarzenie, które się przytrafiło u stóp góry S. Gotharda. W głębi jaskini postrzeżono ciało człowieka, około 30 lat mającego, pod stosem lodów z lawiny pochodzących. Ponieważ ciało to zdawało się tak świeże, jak gdyby dopiero od pół godziny obumarło, doktór Hotham kazał je wydobyć, a zdjąwszy z nego suknię, włożył w zimną wodę, tak, iż wkrótce pokryło się lodem. Potem włożono je w wodę letnią, a potem w cieplejszą: położono je potem na ciepłym łóżku i udzielono ratunku jaki się zazwyczaj zmarzniętym udziela. Nareście przywrócono go do życia; jakżę się wszyscy zdziwili, gdy ten człowiek odzyskawszy zmysły, oświadczył w języku angielskim, że jest Roger Dodsworth, urodzony w r. 1629, i że powracając z Włoch w 1660 w rok po śmierci swego ojca, przywalony został lawiną!! Doktór Hotham powinien był przydać, że P. Dodsworth czuje wielkie odrętwienie we wszystkich stawach, lecz że to przeminie. Jeżeli P. Dodsworth zupełnie ozdrowiawszy, powróci do ojczyzny po 166 latach, wzbudzi zapewne niezmierną ciekawośćc 14 .

Tego samego dnia notka pojawiła się w „Monitorze Warszawskim”"15, potem zaś jeszcze w „Kurierze Warszawskim” z 16 lipca 1826 r. ${ }^{16}$. Podobna relacja znalazła się w wydanych w 1828 r. Rozmaitościach literackich z roku $1828^{17}$. Tak jak

14 „Gazeta Korrespondenta Warszawskiego i Zagranicznego” 1826, nr 112, s. 1680.

15 „Monitor Warszawski” 1826, nr 85, s. 392.

16 „Kurier Warszawski” 1826, nr 167, s. 691.

17 Rozmaitości literackie z roku 1826, t. 2, Warszawa 1828, s. 312-313. 
w angielskiej prasie, również na terenach polskich poza krótkimi sensacyjnymi informacjami trudno znaleźć kontynuacje tego wątku.

\section{Mary Shelley a Roger Dodsworth}

Mary Shelley niejednokrotnie poruszała w swej twórczości tematykę życia i śmierci. Inspiracją z pewnością był dla niej jej ojciec William Godwin, autor powieści St. Leon (1798), poruszającej problematykę magicznych eliksirów i fizycznej nieśmiertelności. Najgłośniejszym utworem angielskiej pisarki związanym z tym tematem jest Frankenstein, czyli nowy Prometeusz (1818), jednak w kolejnych latach powstały też Valerius. The Reanimated Roman (1819), Roger Dodsworth. The Reanimated Englishman (1826, publ. 1863) oraz The Mortal Immortal (1833, publ. 1873). Wśród inspiracji i fascynacji autorki wskazywano między innymi legendę o siedmiu braciach śpiących z Efezu, dzieje Nurzahada oraz Ripa Van Winkle ${ }^{18}$.

Utwór dotyczący Rogera Dodswortha Shelley napisała już w 1826 r. W tym samym roku wysłała go do Cyrusa Reddinga z redakcji „New Monthly Magazine”. Tekstu jednak wówczas nie opublikowano, pojawił się dopiero w 1863 r. w zbiorze Reddinga Yesterday and To-day ${ }^{19}$. Dzieło przywróciło pamięć o słynnej, choć nieco już zapomnianej historii, ale trudno mówić, by wpłynęło w zdecydowany sposób na kształtowanie się motywów reanimacji zamrożonych ludzi, szczególnie że w międzyczasie w czasopiśmie „Fact and Fiction” ukazało się opowiadanie Lydii Marii Child Hilda Silfverling (1846), w którym autorka zarysowała motyw podróży w czasie przez zamrożenie ciała. Co więcej, zamiast przypadkowej lawiny autorka wprowadziła wątek naukowca, który celowo poddaje tytułową bohaterkę zabiegowi krioprezerwacji, by po stu latach kolejne pokolenia mogły przywrócić ją do życia ${ }^{20}$.

Zdaniem Arnolda A. Markleya Shelley wprowadziła do Rogera Dodswortha pewne wątki satyryczne ${ }^{21}$, choć wydaje się, że autorka skupia swoją uwagę przede wszystkim na refleksjach o konsekwencjach pojawienia się w nowej epoce człowieka, który pochodzi niejako z innego świata. Pisarka dość jasno sugeruje, że wierzy w możliwość utrzymania przy życiu zamrożonego ciała ${ }^{22}$. Wybór formy literackiej jest dość intrygujący. Nie jest to bowiem fabularne opowiadanie, lecz esej z pewnymi przemyśleniami na temat potencjalnego wykorzystania

18 Tak Ch.E. Robinson, op. cit., s. 26. Zob. także P. Young, Fallen from time: The mythic "Rip Van Winkle”, „Kenyon Review” 1960, nr 4, s. 547-573.

19 Kolejna publikacja zaś miała miejsce dopiero w 1976 r. w zbiorze Collected Tales and Stories.

20 Szerzej zob. C.L. Karcher, Patriarchal society and matriarchal family in Irving's "Rip Van Winkle” and Child's "Hilda Silfverling”, „Legacy” 1985, nr 2, s. 31-44.

21 A.A. Markley, "Laughing That I May Not Weep": Mary Shelley's Short Fiction and Her Novels, „Keats-Shelley Journal” 46, 1997, s. 113.

22 M. Shelley, Collected Tales and Stories with Original Engravings, red. Ch.E. Robinson, Baltimore-London 1990, s. 43-50. 
wspomnianych doniesień prasowych jako źródła dla powieści. Elena Anastasaki zwraca uwagę, że zamiast stworzyć pewną fabułę, Angielka skupiła uwagę na refleksjach o literaturze i możliwościach tworzenia narracji w różnych sytuacjach, gdy ten sam umysł znalazłby się w różnych okresach historii ${ }^{23}$.

\section{Podsumowanie}

Góry w wielu tekstach kultury pełnią rolę pewnego rodzaju drzwi czy granic do innego czasu. Obok tradycyjnych, magicznych wizji przyjmują one czasem postać naturalnych pułapek, które mogły, według pewnych poglądów, zatrzymać czyjeś życie, nie przerywając go jednak definitywnie. Plotka o losach Rogera Dodswortha wyrosła właśnie z tego rodzaju przekonań. Z naukowego punktu widzenia wydaje się ona nieco spóźniona, gdyż już pod koniec XVIII w. badacze zgodnie twierdzili, że raczej niemożliwe jest ożywienie ciała zamrożonego przez tak wiele lat. O krioprezerwacjach, które spopularyzowano w latach sześćdziesiątych XX w., jeszcze wówczas nie myślano. Esej Mary Shelley, w którym poruszyła wątek Dodswortha, nie spowodował większego zainteresowania tą tematyką, wbrew temu, co wydają się sugerować przeceniające znaczenie tych refleksji artykuły i opracowania naukowe z XX w. Nie widać wzrostu zainteresowania tą tematyką po publikacji wspomnianego utworu w 1863 r. Trudno dostrzec wpływ utworu Shelley na późniejsze teksty literackie, takie jak The resurrection of Jimber-Jaw (1937) Edgara Rice'a Burroughsa, lub znane filmy Hibernatus (reż. E. Molinaro, Francja-Włochy 1969), Człowiek z lodowca (Iceman, reż. F. Schepisi, USA 1984), Jaskiniowiec z Kalifornii (Encino Man, reż. L. Mayfield, USA 1992). W tradycji motywu gór jako swoistych wehikułów czasu postać Rogera Dodswortha odgrywała pewną rolę, choć z pewnością ówczesny potencjał literacki tej postaci nie został wykorzystany do stworzenia szerszej fabuły.

Powrót do życia był interesującym tematem dla romantyków. W wypadku Mary Shelley to zainteresowanie jest szczególnie widoczne, a jego dowodem jest nie jeden, ale kilka utworów. W wypadku dziejów Rogera Dodswortha dla autorki istotną kwestią nie było jednak ostrzeżenie przed nauką i dwuznacznymi moralnie zabiegami, jak we Frankensteinie, ale refleksja o tym, jak mogłoby wyglądać życie człowieka, który z dnia na dzień znalazł się w innej epoce.

Rola gór w historii omawianej legendy jest niewielka. Góra św. Gotharda stanowi jedynie punkt wyjścia narracji o hibernatusie. Alpejska jaskinia stała się wehikułem czasu, pewnym katalizatorem wieloletniego snu. Ani w doniesieniach prasowych, ani w rozważaniach Shelley nie pojawia się szersza refleksja na temat

23 E. Anastasaki, op. cit., s. 31. 
samego pobytu wśród szczytów. Głównym problemem w tej historii miały być problemy człowieka obudzonego po ponad 100 latach.

\section{Bibliografia}

Anastasaki E., The trials and tribulations of the "revenants": Narrative techniques and the fragmented hero in Mary Shelley and Théophile Gautier, „Connotations” 2006/2007, nr 16.

A relation of an Extraordinary Sleepy Person At Tinsbury, near Bath, [w:] W. Oliver, A Practical Dissertation on Bath Waters, London 1707.

Grabowski B., Podania o śpiacych rycerzach, „Bluszcz” 1881, nr 40, 41, 42.

Hajduk-Nijakowska J., Temat śpiącego wojska w folklorze polskim. Próba typologii, Opole 1980.

History of Artificial Cold, Scientific, Technological and Cultural Issuess, red. K. Gavroglu, Dordrecht 2014.

Hunter J., The Works of John Hunter, F.R.S. with notes, red. J.F. Palmer, t. 1, London 1835.

Karcher C.L., Patriarchal society and matriarchal family in Irving's "Rip Van Winkle" and Child's “Hilda Silfverling”, „Legacy” 1985, nr 2.

Kite Ch., An Essay on the Recovery of the Apparently Dead, London 1788.

Markley A.A., ,Laughing That I May Not Weep”: Mary Shelley's short fiction and her novels, „Keats-Shelley Journal" 1997, t. 46.

Microscopical observations on the materials of the brain, and the ova of animals, to show the analogy that exist between them, by sir Everard Home, „The Edinburgh Medical and Surgical Journal" 1826, 26.

Mnich i wieczność, [w:] Legendy chrześcijańskie. Antologia, t. 1, wyb. S. Klimaszewski, L. Santucci, wprow. S. Klimaszewski, Warszawa 2006.

Moore T., The Poetical Works in Five Volumes, t. 4, Leipzig 1842.

Robinson Ch.E., Mary Shelley and the Roger Dodsworth Hoax, „Keats-Shelley Journal” 24, 1975.

Rozmaitości literackie z roku 1826, t. 2, Warszawa 1828.

Shelley M., Collected Tales and Stories with Original Engravings, red. Ch.E. Robinson, Baltimore-London 1990.

Weryho W., Śpiacy rycerze, „Wisła” 3, 1889, z. 2.

Woolley R., Reanimating Scenes of History: The Treatment of Italy In the Writings of Mary Shelley, Newcastle 2001.

Young P., Fallen from time: The mythic “Rip Van Winkle”, „Kenyon Review” 1960, nr 4.

Ziejka F., Z dziejów literackiej sławy śpiacych rycerzy, „Pamiętnik Literacki” 1983, z. 2.

Góry, Literatura, Kultura 11, 2018

(C) for this edition by CNS 